\title{
Using social networking tools for teaching requests to undergraduate Arab EFL learners: a study of pragmatics
}

Adil Mohammed Qadha

University of Bisha, Bisha, Saudi Arabia and Hodeidah University, Hodeidah, Yemen

Baleigh Qassem Al-Wasy

University of Bisha, Bisha, Saudi Arabia and Sana'a University, Sana'a, Yemen, and Hassan Saleh Mahdi

University of Bisha, Bisha, Saudi Arabia and Hodeidah University, Hodeidah, Yemen

\section{Abstract}

Purpose - This study aimed to investigate the impact of social networks on learning requests by Arab undergraduate EFL students.

Design/methodology/approach - Furthermore, both types of requests (i.e. direct and indirect) have been compared under the same condition. A total of 40 Saudi EFL learners participated in this study. Their scores in the pre-test and post-test were compared.

Findings - Results of the post-tests indicated that the experimental groups' performance significantly outscored the control groups. However, no significant difference was reported between the two experimental groups (i.e. direct and indirect).

Originality/value - Requests, as a component of pragmatics, have been investigated extensively in the literature to aid second/foreign language learning. However, little is known about the manner by which social networks could foster learning requests.

Keywords Pragmatics, Request, Direct request, Indirect request, Social networks

Paper type Research paper

\section{Introduction}

The speech act of request is one of the performative speech acts usually practised by a speaker to convey a message to the hearers asking them verbally to do something, either politely or impolitely, directly or indirectly. Nelson, Carson, Batal, and Bakary (2002) defines the speech act of request as a polite demand made by a requester asking for a favor of the other person. This kind of speech act may be a request for a non-verbal activity, i.e. a request for services, or a request for a verbal activity, i.e. a request for information.

(C) Adil Mohammed Qadha, Baleigh Qassem Al-Wasy and Hassan Saleh Mahdi. Published in Learning and Teaching in Higher Education: Gulf Perspectives. Published by Emerald Publishing Limited. This article is published under the Creative Commons Attribution (CC BY 4.0) licence. Anyone may reproduce, distribute, translate and create derivative works of this article (for both commercial and non-commercial purposes), subject to full attribution to the original publication and authors. The full terms of this licence may be seen at http://creativecommons.org/licences/by/4.0/legalcode

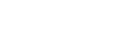




\section{LTHE}

17,2

96

In Saudi Arabia, students of English as a Foreign Language (EFL) need to master the speech act of request because it is the most widely used type of speech act in real communicative situations. Previous studies (e.g. Al-Otaibi, 2015; Alsairi, 2019; Ghazzoul, 2019) have shown that non-native speakers have limited awareness in employing appropriate direct request strategies compared to native speakers. By teaching such a speech act, Saudi learners in higher education will be able to understand and grasp the importance of using requests in naturally spoken discourse. It will also enhance their communicative competence in daily life situations. The present study sought to investigate whether direct or indirect instruction of request speech acts through social media would enhance undergraduate EFL students' performance in Saudi Arabia.

\section{Literature review}

\section{Speech act theory}

Speech act theory was first developed by Austin (1975) and Searle (1969) who claimed that words have primary meaning and carry the message of the speaker. The relationship between pragmatics and speech act theory is strong and inevitable. Speech act theory is the central issue of pragmatics. Many scholars consider pragmatics as the other face of speech act theory (Brown \& Levinson, 1987). In terms of Searle (1969), a speaker performs acts verbally by producing utterances. They are called performative utterances or illocutionary acts. An illocutionary act can be defined as a particular language function performed by an utterance. In other words, a speaker, using performative utterances, can convey many communicative intentions, such as requests, apologies, advice, complaints, greetings, refusals, offers, promises, and thanks. The interpretation of these illocutionary acts is based on the contexts in which they are used and the mutual background information between the speaker and the hearer. Based on his interpretation of the illocutionary act, the hearer can respond to the act verbally or nonverbally. His response to the act is called a perlocutionary act. A perlocutionary act can be defined as a speech act that produces an effect, intended or not, achieved in an addressee by a speaker's utterance (Searle, 1969). There are several speech acts that are usually performed by a speaker in daily conversations, one of which is the speech act of request which is considered the most widely used speech act by speakers.

A request is one of the speech acts usually practised by a speaker to convey a message to the hearers asking them verbally to do something for the speaker. In their daily conversation, people always make requests which reflect that they need each other's help. According to Brown and Levinson (1987), there are two types of requests, direct and indirect requests. Direct requests appear to be inherently impolite and face-threatening because they intrude in the addressee's territory (Brown \& Levinson, 1987; Leech, 2016). On the other hand, indirect requests are usually polite requests. Requests can also be of different kinds according to the context in which they are used. According to Bach and Harnish (1979), there are different subcategories of requests such as requests for action, requests for information, requests for intention, and requests for sympathy.

\section{Researching the speech act of request}

There are many studies conducted about the speech act of request. Some of these studies were conducted in non-Arab countries (Alzeebaree \& Yavuz, 2017; Jalilifar, 2009; Ogiermann, 2009; Sithebe, 2011; Yang, 2016). These studies dealt with the speech act of requests from different perspectives. Some of these studies compared the performance of EFL learners to that of the native speakers in the use of request strategy, showing a significant difference between the performance of native and non-native speakers of English (Jalilifar, 2009; Sithebe, 2011; Yang, 2016). The results of these studies showed some kind of 
pragmatic development, especially in shifting from direct to indirect strategies on the part of EFL learners. EFL learners with high proficiency revealed overuse of the indirect type of requesting whereas the native group was comparatively characterized by the most balanced use of this strategy. On the other hand, the lower profiency EFL learners overused the most direct type of this strategy. With respect to the influence of the social variables, the findings showed that as far as social power is concerned, EFL learners display closer performance to native speakers. But considering social distance, it seems that EFL learners have not acquired sufficient sociopragmatic knowledge to display proper social behavior.

In addition, some studies examined the speech act of request with Arab learners, in general, and Saudi EFL learners, in particular (Al-Otaibi, 2015; Al-Shawesh \& Hussin, 2015; Alsairi, 2019; Aubed, 2012; Ghazzoul, 2019; Saud, 2019). Aubed (2012) compared the use of polite requests in English and Arabic. The findings of this study revealed that expressing polite requests in English and Arabic are not identical. There are more polite forceful markers in Arabic than in English. More than one equivalent Arabic structure can be found for one English polite structure. Also, Ghazzoul (2019) studied the pragmatic failure in polite requests among Arab participants from different cultural backgrounds. It also discussed the effect of directness on the level of politeness in two languages: Arabic and English. The study showed that the problems encountered by Arab EFL learners in making polite requests or responding to invitations can be attributed to the differences in the systems of the two languages, as well as to the cultural difference between them. Similarly, Al-Otaibi (2015) aimed at investigating the interlanguage pragmatics knowledge higher education Saudi students may have when making requests. The study revealed that non-native speakers showed limited awareness in employing appropriate direct strategies compared to native speakers.

Several studies have also been conducted on refusal strategies used by Arab EFL learners. Alsairi (2019) compared the performance of the Saudi learners in the UK with Saudi learners in KSA, in comparison with British native speakers with reference to refusal strategies from a pragmalinguistic perspective. The study revealed a better change in the use of refusal strategies by the Saudi learners in the UK, when compared with the Saudi learners in KSA. Due to their stay in the UK, the performance of the Saudi learners in the UK is similar to that of the British native speakers. Refusal strategies of Saudi EFL learners were also investigated in Saud's study (2019) which indicated that the most popular refusal strategies the participants used were the indirect ones, followed by the direct ones. The request strategies were also investigated in Al-Shawesh and Hussin (2015) revealing that the EFL Arab learners preferred mostly the use of conventional direct requests followed by the conventionally indirect requests.

Together these studies provide significant insights into the importance of teaching requests to EFL learners in general, and Arab EFL students in particular. Some of the studies showed significant improvement in the EFL learners' use of requests. On the other hand, other studies indicated that the differences between the language systems of English and Arabic was a cause for students' low performance in learning requests. Others highlighted the effect of cultural backgrounds on the learners' acquisition of requests; EFL learners living in USA, for example, were compared with EFL learners living in Arab countries. Overall, all the above studies highlighted the importance of teaching requests for Arab EFL learners in order to help them improve their communicative performance.

\section{Pragmatics and language teaching}

Pragmatics deals with how utterances are used by a speaker in a particular context and how they are interpreted by a hearer. Pragmatics has a crucial role in building a communicatively competent speaker; it helps language learners to understand the language 


\section{LTHE}

17,2

\section{8}

forms and functions that are appropriate to many contexts in which a language is used. In other words, pragmatics increases language learners' ability to select the most appropriate verbal-linguistic acts for the different situations they may encounter (Bouton, 1996; Deda, 2013; Mugheri, Qureshi, \& Mugheri, 2018).

In the last few decades, pragmatics has been widely used in language teaching. Teaching materials in both second and foreign language contexts include strong pragmatics components. The aim of those who adopted the integration of pragmatics in language teaching was to develop EFL students' pragmatic competence. Pragmatic competence refers to the ability to understand and use the most accurate and appropriate linguistic forms according to the social and cultural circumstances where the communication occurs.

In the recent years, several studies investigating the use of pragmatics in language teaching have been carried out. A number of these studies examined the status of pragmatic awareness in EFL language classes (Hassan, 2018; Mohammad-Bagheri, 2015; Neddar, 2012; Sorour, 2018). The results of these studies highlighted the importance of developing pragmatic competence among EFL learners. Hassan (2018) summarized the most common obstacles that may prevent Arab EFL learners from improving their pragmatic competence in EFL classes in these points: non-native speaker English teachers; not offering pragmatics courses to either pre-service or in-service teachers; not including pragmatics materials in language teaching materials; large classes; limited contact hours; and, little opportunity for intercultural communication.

\section{Integration of pragmatics in higher education}

The use of technology in the language learning classroom has created ample opportunities for the teaching of pragmatics as it enables students to have meaningful and authentic exchanges in the target language and provides exposure to a wider variety of discourse functions and meaningful interactions that can enhance the learning process.

Studies have been conducted to examine the effect of technology on the development of EFL students' pragmatic competence (see Cunningham, 2016; Cunningham, 2017; Furniss, 2016; Liu, 2007; Yang, 2016). Furniss (2016) explored the impact of a corpus-referred instructional website on native English learners' acquisition of nine Russian routine formulas. Results indicated that the intervention had a durable effect on learners' awareness of the target routine formulas and lowered aural recognition of nonsense formulas. Yang (2016) explored the effectiveness of a self-access website as a tool to teach expressions of gratitude to learners of Mandarin Chinese. The findings indicated that the instruction positively affected the metapragmatic assessment and pragmatic awareness of the learners at two different proficiency levels. Similarly, in an earlier study Liu (2007) investigated the effectiveness of explicit pragmatic instruction on the acquisition of requests by college-level EFL learners in Taiwan. The relative effectiveness of presenting pragmatics through two delivery systems: face-to-face, in-class activities and computer-mediated communication $(\mathrm{CMC})$ via e-mail and WebCT were compared. The results showed that explicit pragmatic instruction had a positive impact on the EFL learners in both the face-to-face activities and the CMC groups. Learners who received explicit pragmatic instruction performed better on the Discourse Completion Task posttest than those who did not. The findings also indicated that technology can be a valuable tool for delivering pragmatics instruction.

More recently, Cunningham (2016) examined speech act production in telecollaborative exchange, focusing on the requesting behavior of American learners of German for professional purposes as they interacted with German-speaking professionals in Germany via synchronous web conferences. The findings provide new insights regarding the nature of second language request production and confirm the utility of pragmatics instruction in 

professionals. Findings indicated that while both groups of speakers used predominantly direct requesting behavior, L1 speakers used significantly more internal modification devices than did L2 learners.

Few studies investigated the effect of technology on the pragmatic competence of Arab learners. The only example that could be found was conducted in the Gulf region by Deveci and Hmida (2017). In their study, Deveci and Hmida investigated the impact of formal email writing instruction on students' pragmatic competence, comparing the performance of native speakers of English with that of Arab university students in an English-medium university in the UAE. The study revealed that teaching email conventions in the context of an academic environment had a significant impact on students' pragmatic competence.

Given the dearth of research studies in the area of pragmatics in the Arab world, the present study aimed to make a significant contribution by researching the effect of explicit instruction of requests to Arab university undergraduate students utilizing a social networking tool. Investigating speech act theory from this perspective, i.e. the social network environments, is a new trend in need of in-depth discussions and studies, especially since this is the age of social media and virtual communication between people. The following research questions guided the current study:

(1) Does the use of Social Networking tools increase Arab students' understanding and use of requests, as measured by pre-, and post-tests?

(2) How do the experimental group participants respond to the use of Social Networking tools in learning requests in comparison to learning the speech act of request through traditional methods of teaching and learning?

(3) How do the participants in the experimental groups respond to learning direct requests in comparison to learning the indirect requests?

\section{The study}

This intervention study adopted an experimental, pre-test/post-test research design to investigate the development of Arab EFL learners' understanding and use of requests through social networking tools.

\section{Participants}

Forty EFL students at a university in Saudi Arabia participated in the study. The learners were enrolled in Level 5 (advanced) in an Applied Linguistics course. Their English language profieciency was equivalent to B1 on the Common European Framework of Reference (CEFR). Participants were divided into four groups: Group 1 - Experimental Direct Request (E-DR) using social networking tools $(N=10)$; Group $2-$ Experimental Indirect Request (E-IR) using social networking tools $(N=10)$; Group 3 - Control Direct Request (C-DR) $(N=10)$; and, Group 4 - Control Indirect Request (C-IR) $(N=10)$. Only students who completed both the pre-test and post-test and who attended all the sessions were included in the experiment.

\section{Intervention}

The study lasted for three weeks. Participants in the control groups (Groups 3 and 4) received instruction on requests in a traditional way, while participants in the experimental 
LTHE

17,2

100

groups (Groups 1 and 2) received explicit instruction on requests through WhatsApp groups. Communication between the participants in the two experimental groups and their instructor occurred within a group in WhatsApp designed especially for this study. This type of communication facilitates the asynchronous interaction of the participants and their instructors. Although interaction in the study was primarily written, the participants could also share their requests orally using audio messages. On the other hand, the communication between the participants in the two control groups and their instructor occurred inside the classroom.

\section{Data collection instrument}

To test learners' pragmatic knowledge, an open-ended Discourse Completion Task (DCT) was used. Open-ended DCT is a measure of learners' speech act performance that consists of a written speech act and it is frequently used for data collection in pragmatics studies (e.g. Ogiermann, 2009; Birjandi \& Rezaei, 2010). A DCT consists of short dialogues that depict a variety of social situations relevant to the speech act under study. Before each dialogue, a brief description of the situation is provided. The dialogue usually begins with a statement that is followed by a blank indicating an unfinished dialogue. Participants are asked to identify the speech act under study.

In this study, the situations were written in a sheet of paper in the case of control group. In the case of the experimental groups the same sitations were posted in a WhatsApp group. Each situation was posted in isolation. Then, the participants had to reply to each situation. For example, the partipants were asked to respond to the following situation "You missed an exam, you want your teacher to reexamine you." Their responses varied. Here are some actual examples from the students' formulated requests:

Direct Request:

Please, give me a make-up exam next week.

Please, doctor, make another test for me at anytime you like.

Indirect Request:

I am sorry doctor. I was ill. So I could not attend the exam. I will be happy if you accept my execuse.

Please, doctor. I could not have the exam because I was in the hospital with my mother. So, give me another chance.

In this study, the open-ended DCT was composed of ten request situations, designed by the authors (see Appendix), to which participants responded in English. The DCT pre-test and post-test were the same. The learners' performance in each of the 10 situations was rated using a five-point scale as shown in Table 1, and the maximum DCT score was 50 points. Three assistant professors from the university where the study was conducted rated the

Table 1.

Raters' rating on participants' performance

\footnotetext{
1 point Minimal attempt to complete the task and/or content frequently inappropriate

2 points Partial completion of the task, content partially appropriate, ideas are undeveloped

3 points Captures some ideas of the task, content partially appropriate, ideas partially developed

4 points Demonstrates essenial ideas of the task, content mostly appropriate, ideas adequately developed

5 points Superior completion of the task, content appropriate, ideas well developed and well-organized

Note(s): Adapted from Liu (2007)
} 
students' DCT performance. They assessed participants' pragmatic competence based on the rating system developed by Hudson, Detmer, and Brown (1992), which contains the following components: the ability to correctly use speech acts; expressions; the amount of information used; and politeness. Participants' performance was rated on a 5-point rating scale, as shown in Table 1 (based on Liu, 2007) and scores ranged from 10 to 50 for four components. Interrater correlations from the moderation study yielded an acceptable level of agreement for interrater reliability $(r>0.90)$.

\section{Procedure}

Before the intervention, the pre-test was administered to all the study participants. Then, participants were divided into four groups randomly. Participants in the control groups received instruction on requests in a traditional way. They were given situations to make requests. They were asked to write a direct and indirect request for each situation and submit their answers to the instructor. On the other hand, the participants in the two experimental groups received explicit instruction on two types of requests: direct and indirect. In this case, they were asked to respond to the situations via WhatsApp messages. They could edit and revise before they sent their responses. The two experimental groups were given the same situations to respond to. The first experimental group was asked to provide direct speech act requests whereas the second group was asked to provide indirect speech act requests. The experimental groups were shown videos that contained conversations in which examples of requests were given. In the first experiemental goup, videos with conversations containing direct requests were provided. In the second experiemental goup, videos with conversations containing indirect requests were provided. During the last session, the participants in the four groups were asked to do the post-test which was similar to the pre-test.

\section{Data analysis}

Descriptive and inferential statistical procedures were performed in this study to determine the effect of Social Netwroking tools on learning requests. Using SPSS, an ANOVA was conducted to determine the significance of the differences among the four groups. The level of significance was set at $<0.05$ for all statistical analyses.

\section{Results}

To ensure that the four groups were not different in their production of the target speech acts before the intervention, one-way ANOVAs were performed on the pre-test scores. There were no significant between-group differences in the production of requests. The results of the scores in the pre-test are shown in Table 2. The means of the scores revealed that there was no significant difference between the four groups before the intervention $(\phi=0.849)$ which means that the groups were homogenous.

\begin{tabular}{|c|c|c|c|c|c|c|c|}
\hline & \multirow[b]{2}{*}{$N$} & \multirow[b]{2}{*}{ Mean } & \multirow[b]{2}{*}{ Std. deviation } & \multicolumn{3}{|c|}{$\begin{array}{l}95 \% \text { confidence interval } \\
\text { for mean }\end{array}$} & \\
\hline & & & & Std. error & Lower bound & Upper bound & \\
\hline Experimental DR & 10 & 10.70 & 1.88 & 0.597 & 9.34 & 12.05 & \\
\hline Experimental IR & 10 & 11.00 & 2.10 & 0.666 & 9.49 & 12.50 & Table 2. \\
\hline Control DR & 10 & 10.30 & 1.88 & 0.597 & 8.94 & 11.65 & Participants' scores \\
\hline Control IR & 10 & 10.90 & 1.66 & 0.525 & 9.71 & 12.08 & in the pre-test \\
\hline
\end{tabular}


LTHE

17,2

102

The One way ANOVA of the post-test scores were conducted to examine the effect of Social Networking tools on learning requests. The analysis of variance showed that the effect of Social Networking tools on learning requests was signinifcant $(F(3,36)=4.60$, $p=0.008$ ) demonstrated significant differences between the four groups in the post-test scores. The students' scores in the post-test were analysed and showed that the participants in the experimental groups (E), direct (DR) and indirect requests (IR) (M(E$\mathrm{DR})=40.40$ and $\mathrm{M}(\mathrm{E}-\mathrm{IR})=40.90$ respectively) scored higher than the participants in the control groups, direct $(\mathrm{C}-\mathrm{DR})$ and indirect requests $(\mathrm{C}-\mathrm{IR})(\mathrm{M}(\mathrm{C}-\mathrm{DR})=34.90$ and $\mathrm{M}$ $(\mathrm{C}-\mathrm{IR})=35.10)$ (see Table 3$)$. On the other hand, the results revealed that there was no significant difference between the experimental groups' scores in producing direct and indirect requests.

Post hoc tests were performed and results are shown in Table 4. The post-hoc Tukey HSD test of gain scores indicated a significant difference between the experimental group direct (E-DR) and the two control groups (C-DR \& C-IR). In addition, there was no statistically significant difference between the experimental group indirect (E-IR) and the two control groups $(p=0.068$ and 0.084$)$. Furthermore, there was no significant difference between the scores of the two experimental groups (E-DR and E-IR) $(\phi=0.996)$.

Eta squared was used to determine the magnitude of effect size. Cohen (1988) proposed that the effect size is small when $\eta^{2}=0.01$, medium when $\eta^{2}=0.06$, and large when $\eta^{2}=0.14$. In this study, the eta square test of gain scores for requests, indicated that both experimental groups significantly outperformed the control groups with large effect $\operatorname{sizes}\left(\eta^{2}=0.52\right)$.

Table 3.

Participants' scores in the post-test

\begin{tabular}{lcccccc}
\hline & & & & & \multicolumn{2}{c}{$\begin{array}{c}9 \% \text { confidence interval } \\
\text { for mean }\end{array}$} \\
& $N$ & Mean & Std. deviation & Std. error & Lower bound & Upper bound \\
\hline Experimental DR & 10 & 40.40 & 4.99 & 1.57 & 36.82 & 43.97 \\
Experimental IR & 10 & 40.90 & 4.43 & 1.40 & 37.72 & 44.07 \\
Control DR & 10 & 34.90 & 5.02 & 1.58 & 31.30 & 38.49 \\
Control IR & 10 & 35.10 & 4.79 & 1.51 & 31.67 & 38.52 \\
\hline
\end{tabular}

\begin{tabular}{llccr}
\hline & & Mean difference & Std. error & Sig. \\
\hline Experimental DR & Experimental IR & -0.50 & 2.153 & 0.996 \\
& Control DR & 5.50 & 2.153 & 0.068 \\
& Control IR & 5.30 & 2.153 & 0.084 \\
Experimental IR & Experimental DR & $0.50 *$ & 2.153 & 0.996 \\
& Control DR & $6.00^{*}$ & 2.153 & $0.040^{*}$ \\
Control DR & Control IR & 5.80 & 2.153 & 0.050 \\
& Experimental DR & -5.50 & 2.153 & 0.068 \\
Control IR & Experimental IR & $-6.00^{*}$ & 2.153 & $0.040^{*}$ \\
& Control IR & -0.20 & 2.153 & 1.000 \\
& Experimental DR & -5.30 & 2.153 & 0.084 \\
Note(s): *Significant at the 0.05 level & -5.80 & 2.153 & 0.050 \\
& Experimental IR & 0.20 & 2.153 & 1.000 \\
\end{tabular}

Table 4.

Post hoc tests

Note(s): *Significant at the 0.05 level 


\section{Discussion}

The study aimed at examining the effect of using social networking tools to increase learners' understanding and use of requests, as measured by pre-, and post-tests. An eta square test of gain scores for requests showed that the experimental groups outperformed the control groups with large effect sizes $\left(\eta^{2}=0.52\right)$. The results of this study are in line with Liu (2007) who also found that technology can be a valuable tool for delivering pragmatics instruction.

With regards to the second research question about how the experimental group participants would respond to the use of social networking tools in learning requests in comparison to learning the speech act of request through ordinary methods of teaching and learning, this study revealed that using social networking tools led to a significant improvement in learners' pragmatic competence with regards to requests. This result is consistent with the findings of Yang (2016) which indicated that the instruction positively affects the pragmatic awareness of the learners.

The application of social networking tools appears to have influenced the learners in the experimental groups helping them to perform better than those in the control groups. This reveals that when learners are allowed to formulate a request using social networking tools, they are more consciously aware of the appropriate forms of the target-language pragmatics. This result is in line with Cunningham (2016) who examined speech act production in telecollaborative exchange.

With regards to the research question about learning direct requests in comparison to learning indirect requests, the results indicated that there was no difference between the participants' scores in the two experimental groups in both conditions (i.e. direct and indirect). The findings of this study contradict the results of Al-Shawesh and Hussin (2015) who found that the EFL Arab learners preferred the use of conventional direct requests followed by the conventionally indirect requests respectively. Also, the findings of this study contradict the results of Saud (2019) and Ghazzoul (2019) which revealed that the most popular refusal strategies used by the participants were the indirect ones, followed by the direct ones.

The above mentioned findings can be justified in terms of the simplicity of using direct requests, rather than indirect requests. In other words, Arab EFL learners face more difficulty in using the indirect requests. Besides, the mother tongue influence plays a major role in selecting the type of requests. In Arabic language, speakers tend to use the direct type of requests rather than the indirect one (Al-Shawesh and Hussin, 2015). This study revealed the same result. During the intervention, the researchers observed that EFL learners preferred the use of the direct requests to the indirect ones. The learners' weak performance in the use of indirect requests can be attributed to their unfamiliarity with this type of requests in their native language.

\section{Conclusion}

The study aimed at examining the effect of using social networking tools to increase Arab learners' understanding and use of direct and indirect requests. The results showed that students who received instruction through WhatsApp (a social networking tool) on direct and indirect requests outperformed the control groups who received traditional, face-to-face instruction in class. The use of the social networking tool led to significant improvement in learners' knowledge and use of requests. This implies that when learners are allowed to formulate requests using social networking tools, they are more consciously aware of the appropriate forms of the target-language pragmatics.

The findings of this study have some pedagogical implications. Using social networking tools in language teaching and learning can enhance Arab students' pragmatic competence and in particular their awareness and use of direct and indirect requests. The findings of the networking tools

for teaching

requests

103 


\section{LTHE}

17,2

study can help language instructors make use of tools such as WhatsApp to increase the number of learner output and make communication between learners and between teacher and learners easier and more effective.

Based on the findings of the study, it is highly recommended that speech acts, in general, and requests, in particular, should be given attention in the EFL classroom and be explicitly included in the curricula of Higher Education isntitutions. It is also recommended that EFL learners be given opportunities to practise using the speech act of requests through the use of social networking tools like WhatsApp. In addition, English language students should be taught of making requests in English in both ways (i.e. directly and indirectly). Understanding how make request politely may lead them to understand how language is actually being used. English language instructors are advised to integrate different learning activities that can stimulate the students' pragmatic awareness as well as develop their communicative competence. Furthermore, English language instructors should inform Arab EFL learners that in English, using indirect request forms is more preferable than direct request forms. In this case, English language instructors can expose their students to the features of requests that native speakers adopt to communicate in certain situations. Finally, teachers can encourage their students to use social networking tools to communicate with native speakers of English using indirect requests.

Despite the importance of the findings, the study is not without limitations. The small sample of the study may affect the generalizability of the findings while the data collection tools could have included some qualitative data to further elicit students' views and attitudes towards the use of social networking tools for learning English. Future research could involve larger samples of Arab university students to study the effect of social networking tools on the acquisition of various types of speech acts, such as greetings, appologies, and compliments.

While limited in its scope, the current study showed that using social networking tools can successfully increase Arab learners' communicative competence. The use of social networking tools creates an environment that contributes to the development of EFL learners' pragmatic knowledge and appropriate use of requests.

\section{References}

Al-Otaibi, S.M. (2015). Saudi EFL students' knowledge in pragmatics - making requests. Arab World English Journal, 6(2), 302-315, doi: 10.2139/ssrn.2834399.

Al-Shawesh, M.Y., \& Hussin, S. (2015). Investigating the request strategies among the Arab international students and Malaysian employees at a university in Malaysia. Arab World English Journal, 6(1), 309-325, doi: 10.2139/ssrn.2834453.

Alsairi, M.A. (2019). Analyzing the Saudi EFL advanced learners' refusal strategies: A pragmalinguistic perspective. British Journal of English Linguistics, 7(2), 15-43.

Alzeebaree, Y., \& Yavuz, M.A. (2017). Realization of the speech acts of request and apology by Middle Eastern EFL learners. Eurasia Journal of Mathematics, Science and Technology Education, 13(11), 7313-7327, doi: 10.12973/ejmste/79603.

Aubed, M.M. (2012). Polite requests in English and Arabic: A comparative study. Theory and Practice in Language Studies, 2(5), 916-922, doi: 10.4304/tpls.2.5.916-922.

Austin, J.L. (1975). How to Do Things with Words. Oxford University Press, London.

Bach, K., \& Harnish, R.M. (1979). Linguistic Communication and Speech Acts. MIT Press, Cambridge, Massachusetts, London.

Birjandi, P., \& Rezaei, S. (2010). Developing a multiple-choice discourse completion test of interlanguage pragmatics for Iranian EFL learners. ILI Language Teaching Journal (Special Issue: Proceedings of the First Conference on ELT in the Islamic World), 6(1, 2), 43-58. 
Bouton, L.F. (1996). Pragmatics and language learning. In L.F., Bouton (Ed.), Pragmatics and Language Learning (pp. 1-20). University of Illinois at Urbana-Champaign.

Brown, P., \& Levinson, S.C. (1987). Studies in Interactional Sociolinguistics, Politeness: Some Universals in Language Usage. Cambridge University Press, Cambridge.

Cohen, J. (1988). Statistical Power Analysis for the Behavioral Sciences. New York, NY: Routledge Academic.

Cunningham, D.J. (2016). Request modification in synchronous computer-mediated communication: The role of focused instruction. The Modern Language Journal, 100(2), 484-507, doi: 10.1111/ modl.12332.

Cunningham, D.J. (2017). Methodological innovation for the study of request production in telecollaboration. Language, Learning and Technology, 21(1), 75-98, available at: http://1t.msu. edu/issues/february2017/cunningham.pdf.

Deda, N. (2013). The role of pragmatics in English language teaching. Pragmatic competence. Academic Journal of Interdisciplinary Studies, 2(4), 63-70, doi: 10.5901/ajis.2012.v2n4p63.

Deveci, T., \& Hmida, I.B. (2017). The request speech act in emails by Arab university students in the UAE. Journal of Language and Linguistic Studies, 13(1), 194-214, available at: https:/www.jlls. org/index.php/jlls/article/view/569/280.

Furniss, E.A. (2016). Teaching the pragmatics of Russian conversation using a corpus-referred website. Language, Learning and Technology, 20(2), 38-60, available at: http://1t.msu.edu/issues/ june2016/furniss.pdf.

Ghazzoul, N. (2019). Linguistic and pragmatic failure of Arab learners in direct polite requests and invitations: A cross-cultural study. Theory and Practice in Language Studies, 9(2), 223-230, doi: 10.17507/tpls.0902.13.

Hassan, S.A. (2018). Exploring the challenges of teaching pragmatic competence in EFL classes. Journal of College of Basic Education for Educational and Human Sciences, 39, 1707-1714.

Hudson, T., Detmer, E., \& Brown, J.D. (1992). A Framework for Assessing Cross-Cultural Pragmatics. Second Language Teaching and Curriculum Center, University of Hawaii.

Jalilifar, A. (2009). Request strategies: Cross-sectional study of Iranian EFL learners and Australian native speakers. English Language Teaching, 2(1), 46-61, doi: 10.5539/elt.v2n1p46.

Leech, G.N. (2016). Principles of Pragmatics. Routledge, London.

Liu, C.N. (2007). Pragmatics in foreign language instruction: The effects of pedagogical intervention and technology on the development of EFL learners' realization of 'request'. Ph.D. Thesis. Texas A\&M University, Texas.

Mohammad-Bagheri, M. (2015). The status of pragmatics among Iranian EFL learners. English Language Teaching, 8(4), 67-79, doi: 10.5539/elt.v8n4p67.

Mugheri, N.A., Qureshi, P.A.A., \& Mugheri, R.A. (2018). The importance of pragmatics in English language teaching. Language in India, 18(6), 113-124.

Neddar, B.A. (2012). Short notes on discourse, interlanguage pragmatics and EFL teaching: Where do we stand?. Procedia - Social and Behavioral Sciences, 46, 5687-5692, doi: 10.1016/j. sbspro.2012.06.498.

Nelson, G.L., Carson, J., Batal, M.A., \& Bakary, W.E. (2002). Cross-cultural pragmatics: Strategy use in Egyptian Arabic and American English refusals. Applied Linguistics, 23(2), 163-189, doi: 10.1093/applin/23.2.163.

Ogiermann, E. (2009). Politeness and in-directness across cultures: A comparison of English, German, Polish and Russian requests. Journal of Politeness Research, 5(2), doi: 10.1515/JPLR.2009.011.

Saud, W.I. (2019). "Refusal strategies of Saudi EFL undergraduate students", Arab World English Journal (AWEJ), The Dynamics of EFL in Saudi Arabia, (Special Issue: The Dynamics of EFL in Saudi Arabia, December 2019), 96-114. 
LTHE

17,2

106

Searle, J.R. (1969). How to derive 'ought' from 'is'. In The Is-Ought Question. Palgrave Macmillan, London.

Sithebe, F.B. (2011). The speech act realization of requests and greetings by non-native and native speakers of siSwati: Communication challenges faced by American Peace Corps Volunteers in their interaction with Swazi people. Doctoral dissertation. Stellenbosch: University of Stellenbosch.

Sorour, N. (2018). Examining ESL learners' grammatical and pragmatic awareness. Arab Journal of Applied Linguistics, 3(1), 78-104, available at: https://files.eric.ed.gov/fulltext/EJ1207971.pdf.

Yang, L. (2016). Learning to express gratitude in Mandarin Chinese through web-based instruction. Language, Learning and Technology, 20(1), 191-208, available at: http://1t.msu.edu/issues/ february2016/yang.pdf.

\section{Appendix. The open-ended DCT test}

Make a request for each of the following situations

(1) You lost your pen and you want to borrow one from your classmate.

(2) You feel very cold; you want your brother to switch off the AC.

(3) You could not reach your destination; you want someone to guide you.

(4) You missed an exam, you want your teacher to reexamine you.

(5) You feel very thirsty; you want your sister to give you a glass of water.

(6) Your car got a flat tyre in a far place, you want someone to help you.

(7) You lost your money in the market, you want your friend to lend you some.

(8) You are in a restaurant; you want to ask the waiter to bring the food fast.

(9) You want your teacher to clarify a point in the lesson you could not understand.

(10) You want the gatekeeper to open the gate for you.

\section{About the authors}

Adil Mohammed Qadha is working as an assistant professor of linguistics in the department of English, College of Arts and Science, Balqarn, University of Bisha, Saudi Araba. His research interests include stylistics, semiotics, and learning a second and foreign language.

Baleigh Qassem Al-Wasy is an assistant professor of applied linguistics in the Department of English, University of Bisha, Saudi Arabia. His research interests are computer-assisted language learning (CALL), Mobile-assisted language learning (MALL), writing skills. He has published a number of articles related to these topics.

Hassan Saleh Mahdi is an assistant professor of applied linguistics in the Department of English, University of Bisha, Saudi Arabia. His research interests are computer-assisted language learning (CALL), Mobile-assisted language learning (MALL), second language vocabulary acquisition. He has published a number of articles related to these topics. Hassan Saleh Mahdi is the corresponding author and can be contacted at: almatari7@gmail.com

For instructions on how to order reprints of this article, please visit our website:

www.emeraldgrouppublishing.com/licensing/reprints.htm

Or contact us for further details: permissions@emeraldinsight.com 